\title{
PROFITABILITY OF WHEAT CROP CULTIVATION IN SUGAR CROP DOMINATED AREA: ECONOMIC AND CLIMATIC STUDY
}

\author{
ELAHI, M. EHSAN ${ }^{1}$, M. SHAH ${ }^{2}$, M. MANSOOR ${ }^{1}$, N. LATIF', \\ N. HUSSAIN ${ }^{1}$, I. I. SADEK ${ }^{3}$ and NAGWA M. AHMED ${ }^{3}$
}

1. Arid Zone Research Center (PARC), Dera Ismail Khan, Pakistan

2. Department of Economic, Gomal University, Dera Ismail Khan

3. Central Lab. for Agricultural Climate (CLAC); Agricultural Research Center (ARC), Giza, Egypt.

(Manuscript received 11 May 2017)

\begin{abstract}
$\mathrm{R}$ ecently, sugarcane largely introduced in "Dera Ismail Khan" (D.I.Khan) Khyber Pakhtunkhwa Province, Pakistan, especially during the summer season. The current study was conducted at Arid Zone Research Centre (AZRC), Dera Ismail Khan (D.I.Khan) to evaluate cost and benefit, as well as climatic profile suitability for wheat cultivation, during 2014/2015 and 2015/2016 seasons. A sample of 200 respondents from 10 major wheat growing villages of the respective areas of the district was interviewed through pre-tested questionnaire. The study revealed that the cost of wheat production was Rs. 35,680 per acres, whereas output comes $1680 \mathrm{~kg}$ per acre (42 mounds) amounting Rs. 63,600 per acres. Farmers' margin also rises by adding the value of family labor and owned land, which is sufficient to sustain a normal family. Moreover, positive influence between return price and output of wheat was concluded from the study, whereas negative effect of cost was also observed. The output elasticity of Land preparation (LP), Seed and Sowing (SS), Farm inputs (FI), Irrigation (Irr), Pesticides / insecticides (Pest) and Harvester threshing (HT) are $0.124587,0.31244,0.5874,0.55461,0.08248$ and 0.65743 , respectively. From climatic point of view, calculated accumulated growing degree days all over the studied seasons at the studied district were about 2663.5 degree days two seasons average. This is sufficient for the used type of wheat at this area to push the different growing stages and present economic crop yield. Key Words: Wheat, Cost, Return, Profit, climatic profile, growing degree days, Cobb-Douglas, Arid Zone, D.I. Khan, Pakistan
\end{abstract}

\section{INTRODUCTION}

In Pakistan, wheat is the leading food grain and staple diet of the people, which occupies the largest agriculture area of the country. Wheat contributes up to 9.9 percent to the value added in agriculture and $2 \%$ to the GDP. Area under wheat cultivation, during 2015-2016, has increased to 9260 thousand hectares from lastyear's area of 9204 thousand hectares, which shows an increase of $0.6 \%$. However, production of wheat stood at 25.482 million tons during 2015-2016, showing an increase of $1.6 \%$ over the last year's production of 25.086 million tons. The production increased as crop was sown at appropriate time and available 
moisture and availability of use of inputs remained adequate. It is grown in almost all provinces including Khyber Paktoon Khawa Province (KPK) (Economic Survey of Pakistan 2015-16).

In D.I.Khan district, wide variety of crops ranging from arid to humid is cultivated. Among these, the most important are wheat, rice, sugarcane, cotton, maize, millet, sorghum, pulses, oilseed, vegetables and fruits. Prior to the inception of "Chashma Right Bank Canal" (CRBC), D.I.Khan, sorghum and millet were the major crops grown in the area. However, after CRBC, sugarcane, rice and orchards took the lead and were largely introduced in the summer season. The area under sugarcane crop has been increased to 15.5 million acres in D.I.Khan, which is the largest in Khyber Pakhtunkhwa province. D.I.Khan is the only district in Pakistan having four Sugar Mills (Chashma-1 ${ }^{-1}$ Chashma-2, Tandlian Wala Sugar Mills Extension Miran and AlMoiz) in working condition while two new Sugar Mills "Al-Mughni" and "Alman Sayyam" are under construction. The present shift of area to sugarcane crop needs to be rationalized in order to meet food requirements of the local masses and maintain production equilibrium in food and industrial crops. Although the area has potential to produce important winter crops (wheat, barley, pulse, oilseed, and fruits), yet there has been constant increase in summer and winter acreage of sugarcane particularly after the commencement of CRBC. Tripathi (1993) analyzed the economics of high yielding wheat variety cultivation for three farm size groups for middle hill and valley farms in Tehri Garhwal district, Uttar Pradesh, India. Data were collected from a sample of 120 farms for $1987 / 88$. The average operational cost was Rs $2431 /$ ha for middle hills farms and Rs 2506/ha on valley farms. Bullock labor accounted for the highest percentage of operational cost followed by manure, fertilizer and seeds. Ahmed et al. (2011) concluded that wheat production contribute significantly to farm sustainability and contribute to alleviation of malnutrition in the State. The actual production constraints restrict the sustainability of this important crop. Soni (2000) conducted a study of the impact of improved wheat production technology, including high yielding varieties with cultural practices and comparing yield, input level and net returns. Farmers adopting advanced technology had $61.92 \%-76.07 \%$ higher yield as compared to the traditional system.

Air temperature is among the most important environmental factors that control plant development, growth and yield. It is a major environmental factor that determines the rate of plant growth and development. All biological processes respond to temperature, and all responses can be summarized in terms of three cardinal temperatures, namely the base or minimum ( $\left.T_{\min }\right)$, the optimum $\left(T_{\mathrm{opt}}\right)$, and the maximum $\left(T_{\max }\right)$ temperatures. The nature of the response to temperature between 
these cardinal points, which is important for calculating the phenology, adaptation and yield of various crops (Shaykewich, 1995). The most common temperature index used to estimate plant development is growing degree days (GDD), or heat unit (HU). The accumulation of GDD determines the time of developmental events, maturity of the crop and yield.

The current investigation aimed to:

- Study the climatic conditions suitability and profitability of wheat crop in the studied area to focus the ever growing food demand of inhabitants of D.I.Khan and rest of the KPK where land availability is much limited.

- To formulate new economically viable cropping pattern having diverse crop rotations.

\section{MATERIALS AND METHOD}

The study was conducted at Arid Zone Research Centre, D.I.Khan, KPK, Pakistan during seasons of 2014/2015 and 2015/2016. For data collection, ten (10) villages were selected randomly, which includes "Himat", "Mandaran", "Ketch", "Lar", "DhapShumali", "Shorkot", "DarabanKalan", "Parova", "LundaSharif" and "Ramak falls" under the command area of Chashma Right Bank Canal (CRBC), D.I.Khan. The analysis is based on the primary data, 200 farmers out of major wheat growers of these areas were considered as samples for study. Necessary information from farmers was collected at their field or home by using pre-tested questionnaireto get the actual data. It included maximum information such as land holding, total cultivated area, area under wheat cultivation etc. However, main focus was on various inputs used in wheat crop production.

\section{Growing degree day's calculations:}

Daily maximum and minimum air temperature were collected from the weather station in Arid Zone Research Centre (AZRC), Dera Ismail Khanduring the period from October to April of both studied seasons of 2014/2015 and 2015/2016. Phenological stages as well as number of days between each stage were recorded and GDD was also calculated for every stage using climatology data with the following equation.

Growing degree days (GDD) calculation:

$$
\text { GDD }=\Sigma\left(\left(T_{\max }+T_{\min }\right) / 2\right)-T_{\text {base }}
$$

Where

$\mathrm{T}_{\max }=$ daily maximum air temperature

$\mathrm{T}_{\min }=$ daily minimum air temperature

$\mathrm{T}_{\text {base }}=$ base temperature $\left(5 \cdot 5^{\circ} \mathrm{C}\right.$ according to Maynard and Hochmuth, 2007). 


\section{Statistical Analysis:}

Econometric view (E-Views)/SPSS package was used to analyze data. The detail is given below: Cost and benefit of wheat will be compared through "Benefit Cost Ratios" (BCR) Samiullah et al. (2014) and Elahi et al. (2015):

Benefit cost ratio of wheat $=\quad T R / T C$

Whereas,

TR (Total Revenue) is the per acre total benefit generated from wheat production TC (Total Cost) is the per acre total cost of wheat cultivation.

Profit Function:

$\Pi=T R-T C$

Where,

$\mathrm{TR}=\mathrm{P} * \mathrm{Q} \quad(\mathrm{P}=$ Price of output and $\mathrm{Q}=$ Output $)$

TC $=\mathrm{V} * \mathrm{X} \quad(\mathrm{V}=$ Input price and $\mathrm{X}=$ Input purchased $)$

Therefore,

$\Pi=\mathrm{PQ}-\mathrm{VC}$

Model of profit function

Empirical model of crop profit function in econometric form is given as:

$\Pi=a+\beta_{1} P+\beta_{2} Q+\beta_{3} C$

The above model described that " $\Pi$ " is determined by the three major factors, which are as under:

$\mathrm{P} \quad=\quad$ Output Price

Q $\quad=\quad$ Output Produced

C $=$ Output Cost

Equations (2), (3) are used to generate equation (4) above. It indicates that profit ( $\Pi$ ) depends on output price (P), total output (Q) and cost per unit (C) of output produced. $B_{s}$ are the parameters to be estimated and measure the change in $(\Pi)$ with a unit change in the variables on right hand side as the case unit changes (Debertin, 2012; Anwar, 2013; Samiullah et al., 2014 and Elahi et al., 2015).

To show the input-output relationship, log linear "Cobb Douglas" production function has been used (Haq et al., 2002 and Hussain and Khattak, 2011).

However, due to some additional variables used in the present study, accordingly it was modified. The following log linear Cobb-Douglas production function was applied, using the least square method:

$$
\begin{gathered}
\ln P=\ln a 0+a 1 \ln \text { Area }+a 2 \ln L P+a 3 \ln S S+a 4 \operatorname{lnFI}+a 5 \operatorname{lnIrr} \\
+a 6 \ln \text { Pest }+a 7 \ln H T+e i \ldots \ldots \ldots \ldots .(5)
\end{gathered}
$$

The above model was then converted into the following general form:

$P w=a o^{\prime}$ Areaa1'LPa2 'SSa3' FIa4' Irr' Pesta6' HTa7' ei. 


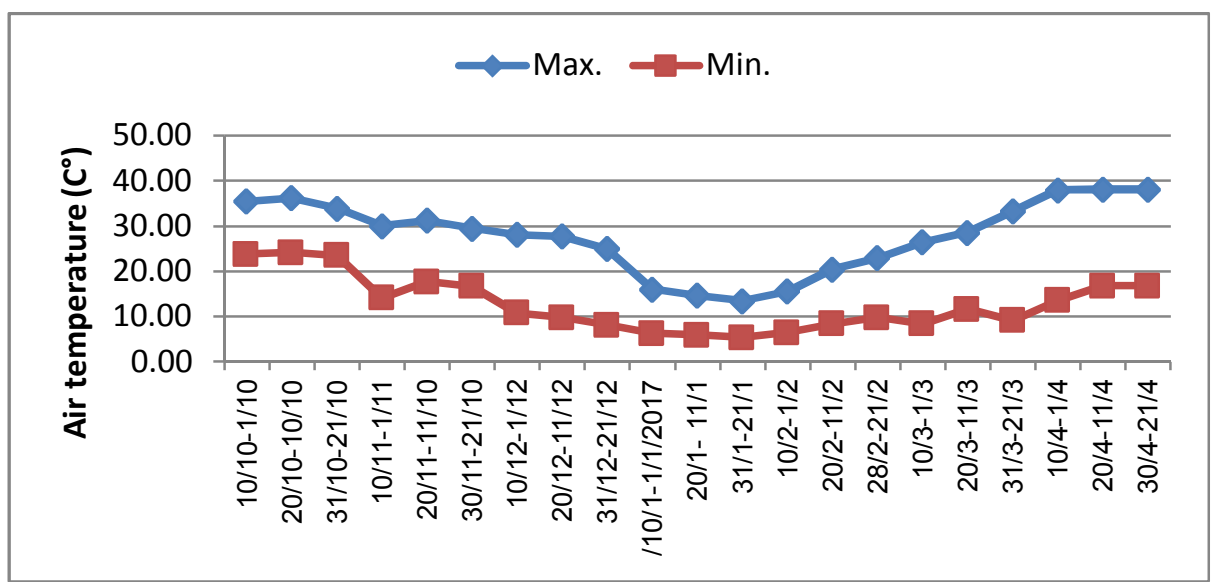

Fig. 2. Maximum and minimum air temperature during seasons of $2015 / 2016$.

\section{Growing degree days:}

Data in Table (1) shown average maximum and minimum air temperature and the monthly accumulative growing degree-days for wheat plants during the growing seasons.

The highest accumulative growing degree days (681.5) was detected during October in both studied seasons. However, accumulation of growing degree-days reduced in November to record 472.0. Contrary, the lowest accumulated growing degree days was found on January (86.5) followed by those accumulated in February (179.5).

All over the growing seasons 2663.5 degree days were accumulated. This number reflected the required degree days for the optimum wheat crop production.

Table 1. Maximum and minimum air temperature and the accumulative growing degree days during wheat growing seasons.

\begin{tabular}{|c|c|c|c|}
\hline Days & Max. temperature $\left(\mathrm{C}^{\circ}\right)$ & Min. temperature $\left(\mathrm{C}^{\circ}\right)$ & GDD \\
\hline October & 33 & 22 & 681.5 \\
\hline November & 28 & 14 & 472.0 \\
\hline December & 27 & 07 & 331.5 \\
\hline January & 13 & 14 & 86.5 \\
\hline February & 17 & 06 & 179.5 \\
\hline March & 27 & 09 & 392.5 \\
\hline April & 34 & 11 & 520 \\
\hline \multicolumn{3}{|c|}{ Total } & 2663.5 \\
\hline
\end{tabular}

Profitability study:

To compare the cost and revenue of wheat, Benefit Cost Ratio (BCR) was calculated by using equation number " 1 ":
$\mathrm{BCR}$ for Wheat =
$\mathrm{TR} / \mathrm{TC}$
$=$
$63,600 / 35,680$
$\mathrm{BCR}$ for Wheat $=$
1.78

The calculated value of $\mathrm{BCR}$ clearly indicates that the wheat cultivation is profitable.

By using equation number " 2 ", net return is calculated as:

Net Return $=\quad \mathrm{TR}-\mathrm{TC}=63,600-35,680$ 
Net Return $\quad=\quad 27,920$

Estimated model as per equation number "4":

$\begin{array}{lll}\Pi \quad= & -0.0052+0.831 \mathrm{P}+0.072 \mathrm{Q}+0.53 \mathrm{C} \\ \text { Standard Error } & = & \{0.004\}\left\{6.12 \mathrm{E}^{05}\right\}\{0.07)\left\{1.03 \mathrm{E}^{-08}\right\} \\ \text { t-ratio } & = & \{-1.69\}\{1548.13\}\{0.75\}\{-753562\} \\ \mathrm{R}^{2} & = & 0.82 \\ \mathrm{R}^{2} \text { (adjusted) } & = & 0.68 \\ \mathrm{~F} & = & 6.39 \mathrm{E}^{20}\end{array}$

F-test determines the overall goodness of fit/significance of the model. It is clear from the above model that the value of f-test is very high.

$F_{\text {calculated }}=6.39 \mathrm{E}^{20} \quad>\quad \mathrm{F}$ tabulated $=3.12$

i.e Calculated value of $f$-statistic is greater than tabulated value of $f$-statistic.

Thus the model shows overall significance.

The co-efficient of determination (R2), signify that the $82 \%$ deviation in the dependent variable has been explained by the independent variables. The sign of independent variables shows that effects of explanatory variables are according to the theory. Whereas, $t_{\text {calculated }}>$ ttabulated $=1.895$, indicates that $\mathrm{t}$-ratios of the factors confirms that, profit of the wheat production ( $\Pi$ ) is significantly determined by the three already mentioned factors of the model keeping all the other inputs constant. Thus, a unit increase in per acre cost of wheat, profits will rise by Rs. 0.83 , producing another $\mathrm{kg}$ of output (Q) will increase the profit by Rs 0.72 while each additional unit of per $\mathrm{kg}$ cost $(\mathrm{C})$ will decrease the profit by Rs. 53. The estimation of the profit function revealed that profit is significantly affected by the above three mentioned factors. However, the effect of cost is higher than the effect of price and output of wheat.

At the end, Cobb Douglas Production Function is calculated through equaton"5" given as under:

$\ln P=3.51008+0.64123 \ln$ Area $+0.124587 \ln L P+0.31244 \ln S S+0.5874 \ln$ FIt

0.55461 In IRR +0.08248 In Pest +0.65743 In HT.

Or in general form is given as:

In $P=33.54094375+$ Area ${ }^{0.64123}+L^{0.124587}+S S^{0.31244}+F I^{0.5874}+$ Irr $^{0.55461}+$ Pest $0.08248+H T^{0.65743}$

It is concluded that Area, LP, SS, FI, Irr, Pest and Hrvt are statistically significant. As per equation $7 \& 8$, the calculated value of wheat area elasticity of production $(0.64123)$ indicates that if wheat area increase by $1 \%$ and all other inputs remain unchanged, production will increase by $0.64 \%$. Similarly, the output elasticity of LP, SS, FI, Irr, Pest and HT are 0.124587, 0.31244, 0.5874, 0.55461, 0.08248 and 0.65743 , respectively, which can be interpreted in the same way. 
Table 2. Average Cost of Production of Wheat Cultivation in D.I.Khan

\begin{tabular}{|l|l|c|c|c|l|}
\hline S.\# & \multicolumn{1}{|c|}{ Item/ Inputs } & Unit & Quantity & $\begin{array}{c}\text { Rate } \\
(\text { Rs. }) / \text { unit }\end{array}$ & \multicolumn{1}{c|}{$\begin{array}{c}\text { Total } \\
\text { expenditure }\end{array}$} \\
\hline 1.1 & Tractor hours & Hours/Acre & 2 & 800 & 1,600 \\
\hline 1.2 & Labor & Man Days & 1 & 400 & 400 \\
\hline 2 & Land Preparation & Rs. & - & - & 2,000 \\
\hline 2.1 & Seed of Wheat & Kg & 40 & 90 & 1,920 \\
\hline 2.2 & Labor (from sowing) & Man days & 1 & 400 & 400 \\
\hline 3 & Seed \& sowing & Rs. & - & - & 2,320 \\
\hline 3.1 & Diammonium phosphate (DAP) & Rs. & 1 & 3480 & 3,480 \\
\hline 3.2 & Urea & Rs. & 2 & 2020 & 4,040 \\
\hline 3.3 & Transportation Cost & Rs. & 3 & 100 & 300 \\
\hline 3.4 & Application (Labor) & Man Days & 1 & 400 & 400 \\
\hline 4 & Farm Inputs & Rs. & - & - & 8,220 \\
\hline 4.1 & Canal & Seasonal & 1 & 800 & 800 \\
\hline 4.2 & Labor & Man Days & 4 & 400 & 1,600 \\
\hline 5 & Irrigation & Rs. & - & - & 2,400 \\
\hline 5.1 & Insecticide / Pesticides & Ks. & - & - & 1600 \\
\hline 5.2 & Spray pumps (Rent) & Per day & 1 & 200 & 200 \\
\hline 5.3 & Application (Labor) & Man Days & 1 & 400 & 400 \\
\hline 6 & Pesticides & Rs. & - & - & 2,200 \\
\hline 6.1 & Harvesting & Per acre & 1 & 1,500 & 1,500 \\
\hline 6.2 & Threshing & Mounds & 40 & 120 & 4,800 \\
\hline 6.3 & Empty bags & Per bags & 20 & 12 & 240 \\
\hline 7 & Harvesting / Threshing & Rs. & - & - & 6,540 \\
\hline 8 & Land Rent & - & - & - & 35,680 \\
\hline & & Tonal & 8 & 1500 & 12,000 \\
\hline & 2 & & & \\
\hline
\end{tabular}

Table 3. Average Total and Net benefit of Wheat

\begin{tabular}{|l|c|c|c|}
\hline \multicolumn{1}{|c|}{ Item } & Quantity (maund*) & Rate (Rs/maund*) & Total Amount (Rs.) \\
\hline Produce & 42 & 1400 & 58,000 \\
\hline Stalk & - & 4200 & 4800 \\
\hline Total Revenue & - & - & 63,600 \\
\hline Net Revenue & - & - & \\
\hline
\end{tabular}

* Maund $=40 \mathrm{~kg}$

Table 4. Economics of sugarcane production on per acre basis

\begin{tabular}{|l|l|l|}
\hline \multicolumn{1}{|c|}{ S.\# } & \multicolumn{1}{|c|}{ Cost Incurring Items acre } & \multicolumn{1}{c|}{ Cost in Rs./acre } \\
\hline 1 & $\begin{array}{l}\text { Land preparation (Ploughing+ harrowing+ ridge } \\
\text { making+ plotting) }\end{array}$ & $2000+1800+600+400=4800$ \\
\hline 2 & Seed (setts) (2.5 tons) & $2.5 \times 4250=10625$ (Rs.170/maund) \\
\hline 3 & Sowing (read as planting) & 1000 \\
\hline 4 & Fertilizers (3 urea bags+ 2 DAP bags) & 8000 \\
\hline 5 & Irrigations (70\% canal irrigations excluding) & 10000 \\
\hline 6 & IPM & 3000 \\
\hline 7 & Harvesting (1000 kg/person/day) & 8000 \\
\hline 8 & Transportation & 7000 \\
\hline 9 & Other & 5000 \\
\hline 10 & Total expenditure & 57425 \\
\hline 11 & Gross income (yield 56 t/ha) & $567 \times 170=96390$ (Rs.170/maund) \\
\hline 12 & Net income & $96390-57425=38965$ \\
\hline
\end{tabular}


Illustrated data in Table (4) showed the economics of sugarcane production, which obtained benefit cost ratio (BCR) as follow: $\mathrm{TR}=96,390$ and $\mathrm{TC}=57,425$, so, net income $=38,965$.

In addition, if a farmer owns his own land, then he is in a position to earn above Rs.39000 per acre (Table 4). To be realistic, this is a meager margin earned by a farmer after caring the sugarcane field for 12-14 months. The fact of matter is that rising prices of fertilizers and irrigation costs are responsible for increasing the cost of production. To make the matter even worse, farmers are deprived of timely payment of their dues by different sugar mills (Iqbal and Iqbal, 2014).

Moreover, from Table (2) and Table (4), noticed that,

Seasonal total investment $=$ net return/total cost

For wheat $=27,920 \div 35,680=0.783$ R.s.

When, for sugarcane $=38,965 \div 96,390=0.404$ R.s.

On the other hand, monthly net return for wheat $=$ net return/growing season (months) For wheat $=27,920 \div 7=3,988.5$ R.s/month, While for sugarcane $=38,965 \div 12=3,247.08$ R.s/month.

From mentioned before, found that, seasonal total investment and monthly net return had greater economic potential for wheat production more than sugarcane production. Whereas, grower cultivated a wheat crop had advanced chance to cultivate other crops through 5 months to complete the year, this lead to increase the net income for grower.

\section{CONCLUSION}

The results indicate that the average cost per acre was Rs. 35,680 and average production (output) of wheat was estimated to be $1650 \mathrm{~kg}$ per acre. Therefore, the gross return of wheat production was Rs. 63,600 per acre. According to this result, the BCR was calculated as 1.78 . Moreover, positive influence between return price and output of wheat was concluded from the study whereas negative effect of cost on the other hand was observed in wheat production. It is concluded that Area, LP, SS, FI, Irr, Pest and HT are statistically significant variables. As per equation $7 \& 8$, the calculated value of output elasticities of Area, LP, SS, FI, Irr, Pest and $\mathrm{HT}$ are $0.64123,0.124587,0.31244,0.5874,0.55461,0.08248$ and 0.65743 , respectively. 


\section{REFERENCES}

1. Ahmed. E., J. Sulaiman and S. Mohd. 2011. Wheat Production and Economics. Am. J. Agric. Biol. Sci. 6: 332-338.

2. Anwar, H. 2013. Economic Analysis of Rice Crop Cultivation in District Swat. J. Agric. Res. 51(2):175-188.

3. Debertin, D. L. 2012. Agricultural Production Economics. $2^{\text {nd }}$ edn.Macmillion Publishing Company, New York, USA. 413p.

4. Elahi, M. E., M. Shah., A. Rashid. and S. Ahmed. 2015. Profitability of Rice Production in District D.I.Khan. Ameri. Eur. J. Agric. \& Environ. Sci. 15 (9):18451848.

5. Government of Pakistan (GOP), Economic Survey. 2015-16. Economic Advisors Wing, Ministry of Finance, Islamabad. www.pbs.gov.pk/publications

6. Haq, Z. A., K. Munir and A. Mukhtar. 2002. Role of Farm size in Input Use and Productivity of Potato in Shigar Valley of Baltistan Area: An Econometric Analysis $\begin{array}{lllll}\text { Sarhad J. } & \text { of }\end{array}$ www.iiste.org/Journals/index.php/JEDS/article/viewFile

7. Hussain, A. and N. R. Khattak. 2011. Economic analysis of sugarcane crop in district Charsada. J. Agric. Res. 49(1):153-163.

8. Iqbal, M. A. and A. Iqbal. 2014. Sugarcane production, economics and industry in Pakistan. American-Eurasian J. Agric. \& Environ. Sci. 14 (12): 1470-1477.

9. Maynard, D. N. and G. J. Hochmuth. 2007. Knott's Handbook for Vegetable Growers. Hoboken, NJ, John Wiley \& Sons, Inc.

10. Samillah, S. Mehmood, Kalimullah, U. Rehmat and Ibrarullah. 2014. Profitability of Rice Production in D.I.Khan. Pakistan J. Agri. Res. Vol. 3, 2014.www.pjar.org.pk/Issues/Vol27_2014No_3/p_244.pdf

11. Shaykewich, C. F. 1995. An appraisal of cereal crop phenology modelling. Can. J. plant Sci. 75:329-341.

12. Soni, S. N. 2000. Economics of Technical Change of Wheat Production in Sagar District, M. P. Crop-Research-Hisar. 19(3):, 452-456.

13. Tripathi, R. S. 1993. An economic analysis of high yielding wheat cultivation in the rainfed condition of north-central Himalaya. Annals of agricultural Research. 14:199-204. 


\section{جدوي زراعة القمح في مناطق زراعة المحاصيل السكرية : مفهوم إقتصادي ومناخي}

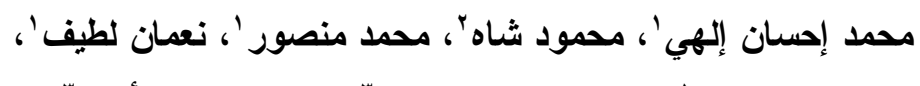

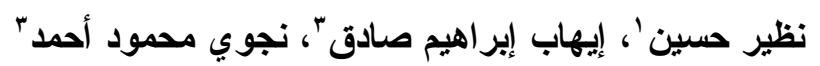

$$
\begin{aligned}
& \text { ا ـ ـ مركز بحوث المناطق الجافة - دير ا إسماعيل خان - باكستان. } \\
& \text { r ـ قسم الإقتصاد -جامعه جومال - دير ا إسماعيل خان - باكستان. }
\end{aligned}
$$

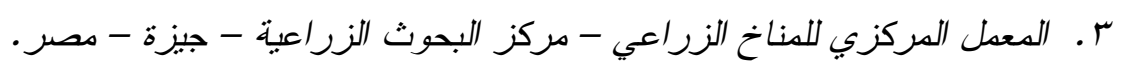

أجريت هذه الدراسة في مركز بحوث المناطق القاحلة، ديرة إسماعيل خان (ديخان)- باكستان بهدف نقييم إنتاج القمح ضمن زمام منطقة نتتهر بزر اعة المحاصيل السكرية. نم التقييم من ناحيتي

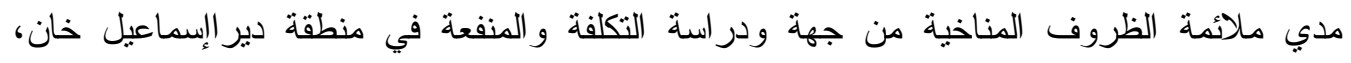

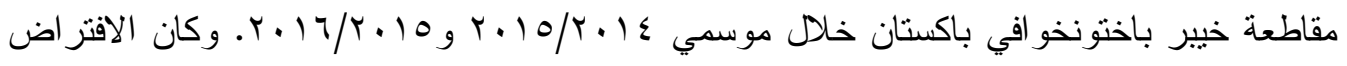

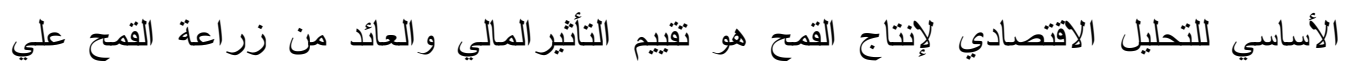

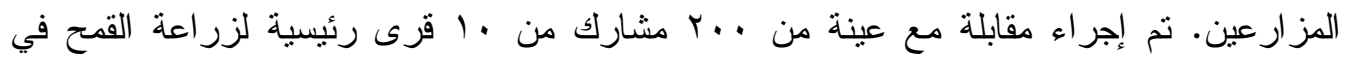
المناطق محل الدر اسة من خلال استبيان تم اختباره مسبقاً.

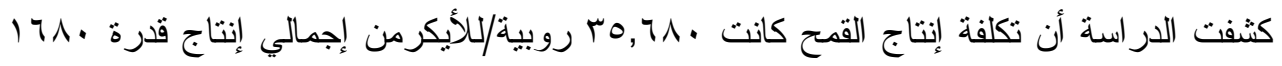
كجم للأيكر. كما يرتفع هامش الربح المتحقق للمزارعين بسبب إضافة قيمة العمل الأسري و الأر اضي المملوكه لهؤلاء المز ارعين. وعلاوة على ذللك، تم التوصل إلى تأثثر إيجابي لسعر القمح.

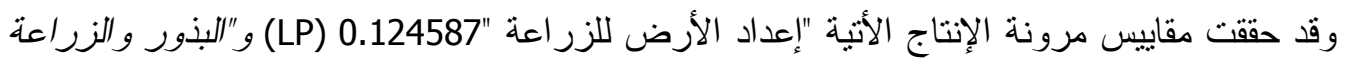

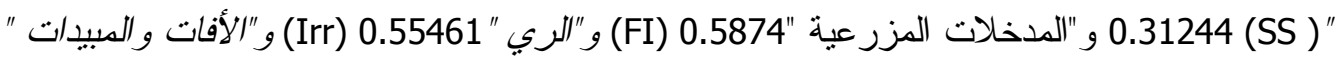

$$
0.08248 \text { و الحصاد } 0.65743
$$

من وجهه النظر المناخية، نراوحت درجات الحراره المتجمعة طوال كل موسم من موسي

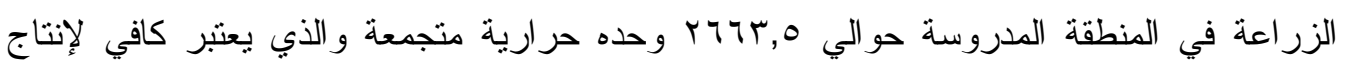

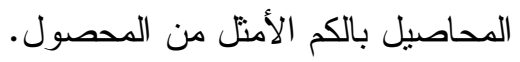

